\section{Case Reports in} Acute Medicine
Case Rep Acute Med 2021;4:95-96

DOI: 10.1159/000520949

Published online: December 9, 2021 (c) 2021 The Author(s)

Published by S. Karger AG, Basel www.karger.com/cra

This article is licensed under the Creative Commons Attribution-NonCommercial 4.0 International License (CC BY-NC) (http://www.karger.com/Services/OpenAccessLicense). Usage and distribution for commercial purposes requires written permission.

\title{
Erratum
}

\section{Erratum}

In the article "Bell's Palsy Caused by SARS-CoV-2" [Case Rep Acute Med. 2021;4:91-94, DOI: $10.1159 / 000520124]$ by Al-Kaisy et al., Figures 1 and 2 were mislabeled. The Figures and Figure legends should be as follows:

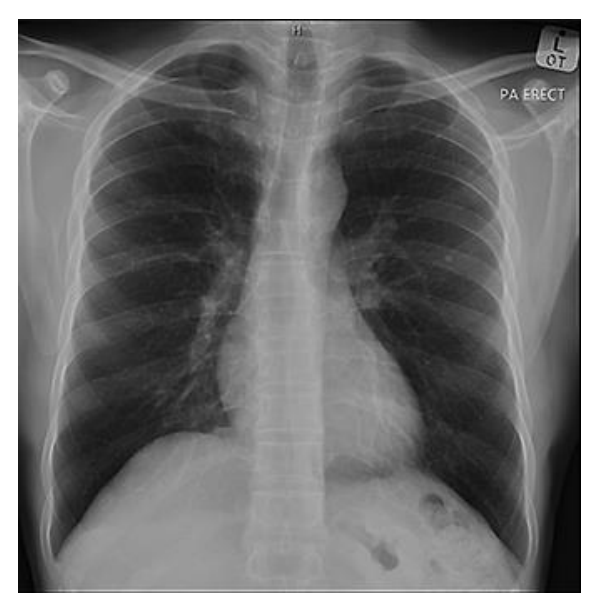

Fig. 1. Chest X-ray showed no lung collapse or consolidation with no signs of COVID-19 infection.

\section{Karger'}






Fig. 2. Brain CT with intravenous contrast showed no signs of infarction, hemorrhage, space-occupying lesion, or cerebral venous thrombosis. 